\title{
Long Term Conventional Bonds versus Long Term Sukuk Issuances and Their Determinants in Malaysia
}

\author{
Noriza Mohd Saad ${ }^{1}$, Mohd Nizal Haniff ${ }^{2}$ and Norli Ali ${ }^{3}$ \\ ${ }^{1}$ Department of Finance \& Economics, Universiti Tenaga Nasional, 26700 Muadzam Shah, \\ Pahang, Malaysia, \\ ${ }^{2,3}$ F Faculty of Accountancy, Universiti Teknologi Mara, 42300 Puncak Alam, Selangor, \\ Malaysia.
}

\begin{abstract}
Both instruments, either conventional bonds or sukuk (Islamic bonds) were trading under the same roof, in the secondary market and through over the counter in Malaysia. The main different is relying on sukuk trading shall be halal in transactions and fully compliant to shariah Islam but for conventional bonds is not restricted to this constituent. The objective of this study is to investigate the mean different between performance of sukuk and conventional bonds. Throughout, this study focused on the sample of 256 tranche of issuances consists of conventional bonds and sukuk with number of observations of 112 and 144 respectively. Secondary data is gathered from Bank Negara Malaysia (BNM) bond information Hub for fifteen conservative year's period from 2000 to 2014. The methods of independent sample T-test and Levene's test are employed in order to test the hypothesis. Interestingly, results revealed there is a significant mean different between long-term conventional bonds and sukuk performance denoting that these two debt instruments are performed in different ways even though trading in the similar marketplace.
\end{abstract}

\section{Key words: Conventional Bonds, Sukuk, Performance, Malaysia}

\section{INTRODUCTION}

In Malaysia, the development of sukuk market (with the first issuance by Shell Company in 1990) is considered relatively new compared to bond market (traded since pre-independence time; 1957). Even though sukuk is a new investment option in the capital market has received an increasing demand as 'halal' investment. It was proven by statistical data reveal by SC regards to size of sukuk issuances traded is higher in 2005 (i.e, sukuk up to MYR43,317m and conventional bonds up to MYR17,346m) and 2006 (i.e, sukuk up to MYR42,019m and conventional bonds up to MYR33,814m) as compared to conventional bonds. Islamic Finance Information Services (IFIS) February 10, 2008 also mentioned in report released that sukuk market continues to enjoy a year -on-year increase despite a slowdown in the rate of growth. However, a drop in the number of sukuk issued in Southeast Asia mainly result of a fall in Malaysian corporate medium-sized issuance.

Firms and even governments are sometimes faced with the problem of scarcity of funds to finance economic transformations and innovations. The massive fund requirements are often unlikely to be serviced by commercial banks. The main sources of the funding are from financial institutions as well as the public. The instruments used are through the sale of bonds, shares, and debt and equity, both in conventional and Islamic systems. The source of funding for such projects is from the capital market which a platform for trading of these financial instruments. Debt capital or bonds are actually loans taken by firms from a huge pool of investors when facing credit problem required in the business operation that require more capital than their bankers can lend. Thus, the bondholders are lenders to the firms. As debtors, the firms which are termed issuers are required to make a contractual payment obligation with respect in the form of interest as a cost of debt or yield until the maturity date of the issuances regardless of the firm's performance. In contrast to the return received by shareholders in the form of dividends depend on the performance of the firm they collectively own.

Usually, capital raise from sukuk and conventional bonds issuance is used to invest in the 
Noriza Mohd Saad / International Journal of Business and Management, 2 (2) 2018, Pages: 17-25

underlying assets [1-3]. In addition, the issuance of Islamic Bonds has undergone rapid increase; for example, London based financial institutions had arranged more than a dozen Islamic Bonds issuances on behalf of Middle Eastern clients in 2006. While in 2008 Indonesia would increase the sale of both sukuk and conventional bonds in order to generate a domestic source of finance to resolve its financial discrepancy [4-6] .

The remainder of the study is structured as follows. Section 2 will reviews the existing literature on conventional bonds and its determinants as well as corporate governance mechanism. Section 3 describes the data and methodology. Section 4 presents the results and discussion and section 5 conclude and recommendations to the issuer.

\section{LITERATURE REVIEWS}

Conventional bonds or sukuk, both have an important facet that is needed to analyze as a measurement by default risk, i.e, yield spreads. A number of researchers discussed about the factors that may impact the yields spreads such as, corporate governance practices by firms include institutional ownerships, blockholders, board of directors [7-18].

As claimed by many authors, corporate governance mechanisms is one of the indicators for code of best practice by the listed firms are actually can reduce default risks by mitigating agency costs and monitoring managerial performance and by reducing information asymmetry between the firm and the lenders[8, 19-20]. Institutional investors monitor the performance of companies [21] and they are considered as advanced investors and better to utilize current information in order to predict future earnings compared to other types of shareholders, bid to create more liquidity and enhance transparency [22].

Recent surge of studies have identified on conventional bonds linked between several governance mechanisms with bond performance. For instance, institutional investors and outside directors affect yields [8, 12]. In addition, the effects of institutional blockholders and independent boards to firm cost of capital and performance [23]. Otherwise there are a few studies in investigating yields of sukuk with corporate governance mechanisms covers a scope of institutional ownership, independent commissioners, audit committees, managerial ownership, blockholders and sukuk in Indonesia [24-25].

Besides that, the influence of institutional investors who are purchased and held the corporate bonds and sukuk rather than individual investors might be a significant factor to yields. As an institutional ownership, supposed they will actively monitoring and pressure more sensitive towards performance of credit and defaults risk as measured by yields of bond and sukuk. Here, many researchers focused on the impact of corporate governance mechanisms on bonds ratings and yields performances and most of the study did not distinguished between conventional bonds and sukuk. Thus, the outcome of these analyses may not be appropriate any longer considering that the sukuk market has greatly developed and has come out with various sukuk products with unique features which are clearly distinguishable from conventional bonds. Therefore, the impact of corporate governance mechanisms on the yields of sukuk might be different from conventional bonds.

Currently, MSWG and SC [26] in the Malaysian Code for Institutional Investors revealed that there are six institutional investors actively involved in the public listed companies. Besides that, they are also a members of the Steering Committee comprised CEOs and also key representatives from the institutional investors' fraternity in Malaysia. The six key institutional investors are Employees Provident Fund of Malaysia (Kumpulan Wang Simpanan Pekerja), National Equity Corporation (Permodalan Nasional Berhad), Retirement Fund Incorporated (Kumpulan Wang Persaraan-Diperbadankan), Pilgrims Fund Board (Lembaga Tabung Haji), Armed Forces Fund Board (Lembaga Tabung Angkatan Tentera) and Social Security Organisation (Pertubuhan Keselamatan Social) and others institutional investors from Malaysian Association of Asset Managers (Persatuan Pengurus Aset Malaysia), Malaysian Takaful Association (Persatuan Takaful Malaysia) and Private pension Administrator (Pentadbir pencen swasta) [27].

\section{DATA \& METHODOLOGY}

This study utilizes the secondary data. First, with respect to the issue characteristics data such as yield, size of issuances, volatility and tenure or length of years trading in which retrieved from bondinfo hub, Bank Negara Malaysia then match with the Rating Agency Malaysia (RAM) in their published Bond newsletters. Second, data are handcollected from the analysis of companies' annual report for corporate governance mechanism regarding on institutional ownerships and board of directors in main market of Bursa Malaysia. Specifically, data on board of directors are gathered from the directors' statement and data on institutional ownership are gathered from the top thirty of shareholdings listing page. Third, an empirical data on firm's issuer performance, i.e, ROA (profitability), Leverage, Tobin's Q (Firm value), Total Assets (Firm size) and SGR (Sustainability) were gathered from Thompson DataStream and Bloomberg software. Fourth, data on gross domestic product are gathered from Department of Statistic, Malaysia. For all the data, it was covers for unbalanced panel data on the sample 
Noriza Mohd Saad / International Journal of Business and Management, 2 (2) 2018, Pages: 17-25

of 256 tranche of issuances consists of conventional bonds and sukuk with 112 and 144 observations respectively from year 2000 to 2014 .

Then, the study compare the performance of long term conventional bonds and long term sukuk by using descriptive statistics and independent sample T-test. The hypotheses developed for this study are as follows:

Ho: The performance of long-term sukuk behaves similarly with long-term conventional bonds.

Ha: The performance of long-term sukuk behaves differently with long-term conventional bonds.

\section{RESULT ANALYSES AND DISCUSSIONS}

Both instruments, either sukuk or conventional bonds were trading under the same roof, in the secondary market and through over the counter in Malaysia. Theoretically, the main different is relying on sukuk trading shall be halal $[22,28]$ in transactions and fully compliant to shariah Islam [29-30] but for conventional bonds is not restricted to this constituent. Besides, it was found evident that sukuk offers unique benefits to corporate issuers unlike those of the conventional bonds through trade off and pecking order theory tested on firm's target debt optimizing behavior [31]. However, empirical evidence can be seen from the statistical results in the Table 1 from year 2000 to 2014. Yield spreads of long term conventional bonds reported higher mean (2.437) as compared to long term sukuk yields with mean slightly lower (1.946) at variance of 0.491 . Thus, indicate the sukuk yield spreads was performed better because wider range of spread by conventional bonds given a huge chance for default risks incur. Similar to Mossaid and Boutti [32] found that a significant and positive correlation between returns of sukuk and bond portfolios.

With respect to variation of risks represented by standard deviation shows that long term sukuk indicate higher risk at 1.717 as compared to long term bonds at lower risk for 1.565 of standard deviation value. This implies that, the sukuk issuances carry higher risk than conventional bonds. This finding was supported by Fathurahman and Fitriati [33] used yield to maturity indicate that yield of sukuk greater than the average returns on conventional bonds as measured by standard deviation for the sukuk is relatively larger than the standard deviation of conventional bonds. However, contradiction of the findings reveal by Ramasamy, Munisamy and Mohd Helmi [34] whereby the yield spread of sukuk actually less risky compared to conventional bonds. Consequently, the level of risks by issuing sukuk and conventional bonds do not seem similar pattern to the issuer. Again, it was supported by Safari, Ariff and Mohamed [35] by arguing that some significant differences between the yield curves of sukuk securities and those of conventional bonds of the same issuers for the same term and rating. Results show significant differences between the average yields of sukuk and those of conventional bonds with the same quality and term issued by the same issuers from 2005 to 2012 . Granger causality tests confirm that the yields of bonds do not Granger-cause the yields of sukuk, verifying no causality between the two. There is strong empirical evidence that the two types of debt instruments are not the same. Similar results revealed by Cakir and Raei [36], where the correlations of sukuk returns are much smaller compared to conventional bonds implying that the yield which is cost to issuer and return to sukukholder and bondholders indicate low for sukuk.

The riskier of the sukuk's yield spread compared to conventional bonds also represented by little variation changes in mean of systematic risks, for instances; log of gross domestic product at the current price (long term sukuk = 13.365 and long term conventional bonds $=13.283$ ) and other market indexes such as producer price index (long term sukuk $=105.317$ and long term conventional bonds $=103.764$ ) and industrial production index (long term sukuk $=103.476$ and long term conventional bonds $=99.891$ ). The argument was supported by Ellis [37] whereby macroeconomic risks are one of the factors to differentiate yield spreads between sukuk and conventional bonds in long run besides market indexes [32].

With respect to the presence of top-six of institutional investors in the firms by their percentage of ownership favors to issuer with long term conventional bonds issuances. It shows that issuer who issue long term conventional bonds indicate higher percentage of share ownership by top-six of institutional investors at mean of 19.188 $\%$ compared to long term sukuk at mean of $13.508 \%$. However, without presence of top-six of institutional ownership which is represent by others institutional ownership indicate that long term sukuk is higher mean at $59.599 \%$ as compare to long term conventional bonds at $52.713 \%$. Here, most of topsix institutional ownership are prefer to invest in the companies that issued long term conventional bonds even though the standard deviation is slightly higher at 23.147 compare to 13.500 . Opposite remark can be explain towards others institutional ownership whereby the standard deviation for long term sukuk indicate lower (17.616) even generate higher mean than long term conventional bonds (24.669). It postulates that they are preferred to invest in the companies that do not monopolize by top-six institutional ownership which is normally related to government- linked investment decision. 
Noriza Mohd Saad / International Journal of Business and Management, 2 (2) 2018, Pages: 17-25

Table 1: Descriptive Statistics Results of Long Term Conventional Bonds and Sukuk

\begin{tabular}{|c|c|c|c|c|}
\hline Variables & $\begin{array}{r}\text { Debt } \\
\text { Category }\end{array}$ & Mean & $\begin{array}{l}\text { Std. } \\
\text { Deviation }\end{array}$ & $\begin{array}{ll}\text { Std. } & \text { Error } \\
\text { Mean } & \\
\end{array}$ \\
\hline \multicolumn{5}{|l|}{ Dependent: } \\
\hline Yield Spreads & $\begin{array}{l}\text { LTB } \\
\text { LTS }\end{array}$ & $\begin{array}{l}2.437 \\
1.946\end{array}$ & $\begin{array}{l}1.565 \\
1.717\end{array}$ & $\begin{array}{l}0.148 \\
0.143\end{array}$ \\
\hline \multicolumn{5}{|c|}{ Institutional Ownership : } \\
\hline IO6 & $\begin{array}{l}\text { LTB } \\
\text { LTS }\end{array}$ & $\begin{array}{l}19.188 \\
13.508\end{array}$ & $\begin{array}{l}23.147 \\
13.500\end{array}$ & $\begin{array}{l}2.187 \\
1.125\end{array}$ \\
\hline Other IO & $\begin{array}{l}\text { LTB } \\
\text { LTS }\end{array}$ & $\begin{array}{l}52.713 \\
59.599 \\
\end{array}$ & $\begin{array}{l}24.669 \\
17.616 \\
\end{array}$ & $\begin{array}{l}2.331 \\
1.468 \\
\end{array}$ \\
\hline \multicolumn{5}{|c|}{ Board of Director Characteristics: } \\
\hline BOD Role Duality & $\begin{array}{l}\text { LTB } \\
\text { LTS } \\
\end{array}$ & $\begin{array}{l}0.214 \\
0.368 \\
\end{array}$ & $\begin{array}{l}0.412 \\
0.484\end{array}$ & $\begin{array}{l}0.039 \\
0.040\end{array}$ \\
\hline BOD Composition & $\begin{array}{l}\text { LTB } \\
\text { LTS }\end{array}$ & $\begin{array}{l}0.036 \\
0.014\end{array}$ & $\begin{array}{l}0.186 \\
0.117 \\
\end{array}$ & $\begin{array}{l}0.018 \\
0.010 \\
\end{array}$ \\
\hline BOD Size & $\begin{array}{l}\text { LTB } \\
\text { LTS }\end{array}$ & $\begin{array}{l}8.884 \\
9.271\end{array}$ & $\begin{array}{l}2.305 \\
2.661\end{array}$ & $\begin{array}{l}0.218 \\
0.222\end{array}$ \\
\hline BOD Muslim & $\begin{array}{l}\text { LTB } \\
\text { LTS }\end{array}$ & $\begin{array}{l}55.032 \\
55.700\end{array}$ & $\begin{array}{l}22.137 \\
23.783\end{array}$ & $\begin{array}{l}2.092 \\
1.982\end{array}$ \\
\hline \multicolumn{5}{|c|}{ Issue Characteristics: } \\
\hline Volatility & $\begin{array}{l}\text { LTB } \\
\text { LTS }\end{array}$ & $\begin{array}{l}1.873 \\
0.928 \\
\end{array}$ & $\begin{array}{l}2.244 \\
1.198 \\
\end{array}$ & $\begin{array}{l}0.212 \\
0.100 \\
\end{array}$ \\
\hline $\operatorname{lnSize}$ issue & $\begin{array}{l}\text { LTB } \\
\text { LTS }\end{array}$ & $\begin{array}{l}5.058 \\
4.150 \\
\end{array}$ & $\begin{array}{l}1.835 \\
1.616\end{array}$ & $\begin{array}{l}0.173 \\
0.135\end{array}$ \\
\hline Tenure & $\begin{array}{l}\text { LTB } \\
\text { LTS } \\
\end{array}$ & $\begin{array}{l}10.491 \\
11.660 \\
\end{array}$ & $\begin{array}{l}9.428 \\
8.995 \\
\end{array}$ & $\begin{array}{l}0.891 \\
0.750 \\
\end{array}$ \\
\hline \multicolumn{5}{|c|}{ Issuer Characteristics: } \\
\hline Profitability & $\begin{array}{l}\text { LTB } \\
\text { LTS }\end{array}$ & $\begin{array}{l}3.014 \\
2.560\end{array}$ & $\begin{array}{l}5.425 \\
4.973\end{array}$ & $\begin{array}{l}0.513 \\
0.414\end{array}$ \\
\hline Leverage & $\begin{array}{l}\text { LTB } \\
\text { LTS }\end{array}$ & $\begin{array}{l}7.233 \\
4.004 \\
\end{array}$ & $\begin{array}{l}5.834 \\
2.953 \\
\end{array}$ & $\begin{array}{l}0.551 \\
0.246 \\
\end{array}$ \\
\hline Firm Value & $\begin{array}{l}\text { LTB } \\
\text { LTS }\end{array}$ & $\begin{array}{l}1.113 \\
1.044\end{array}$ & $\begin{array}{l}0.325 \\
0.266\end{array}$ & $\begin{array}{l}0.031 \\
0.022\end{array}$ \\
\hline Firm Size & $\begin{array}{l}\text { LTB } \\
\text { LTS }\end{array}$ & $\begin{array}{l}9.140 \\
8.672\end{array}$ & $\begin{array}{l}2.725 \\
2.495\end{array}$ & $\begin{array}{l}0.258 \\
0.208\end{array}$ \\
\hline Sustainability & $\begin{array}{l}\text { LTB } \\
\text { LTS }\end{array}$ & $\begin{array}{l}8.110 \\
7.054\end{array}$ & $\begin{array}{l}11.161 \\
4.013\end{array}$ & $\begin{array}{l}1.055 \\
0.334\end{array}$ \\
\hline \multicolumn{5}{|l|}{ Systematic Risks: } \\
\hline $\operatorname{lnGDP}$ & $\begin{array}{l}\text { LTB } \\
\text { LTS }\end{array}$ & $\begin{array}{l}13.283 \\
13.365\end{array}$ & $\begin{array}{l}0.324 \\
0.447\end{array}$ & $\begin{array}{l}0.031 \\
0.037\end{array}$ \\
\hline
\end{tabular}

In terms of board of directors characteristics, their BOD role duality, composition of independent directors, number of directors and percentage of Muslim directors in the company indicate the mean for both, long term conventional bonds (BODR2 $=0.214$ representing that most of the chairman and CEO is hold by different individual, $\mathrm{BODC}=0.036$ means the number of independent directors is more than $1 / 3$ since the mean value is near to $0, \mathrm{BODS}=8.884$ or 9 members of directors, $\mathrm{BODM}=55.032 \%$ of Muslim directors) and sukuk (BODR2 $=0.368$ representing that most of the chairman and CEO is hold by different individual, $\mathrm{BODC}=0.014$ means the number of independent directors is more than $1 / 3$ since the mean value is near to $0, \mathrm{BODS}=9.271$ or 9 members of directors, $\mathrm{BODM}=55.700 \%$ of Muslim directors) are quite similar results. Similar to standard deviation value also indicate not much different. Remarkably, the BOD characteristics do not seem distinguish for the firm who issue long term conventional bonds and sukuk.

Issue characteristics also consider in this study to look into details since most of previous studies mentioned that there is no different between sukuk and conventional bonds [38-40]. There are three main issue characteristics been discussed in 
Noriza Mohd Saad / International Journal of Business and Management, 2 (2) 2018, Pages: 17-25

order to compare the mean different between this debt financing instruments.

High volatility behavior of sukuk market lead to greater uncertainty. Results shows that long term conventional bonds have greater mean (1.873) and standard deviation (2.244) than long term sukuk (0.928 and 1.198 respectively). Suggest that the uncertainty of contribution to return by coupon rate is expose to risk is huge. There is inverse relationship theoretically between coupon rate and value of the bond as similar to yields whereby higher coupon associated to lower bond value and verse versa [41]. Relate with the tenure as a second characteristic to be analyze also indicate longer tenure of maturity expose to the higher risk of uncertainty in return and price of sukuk and bonds. In average, the issuer was issued long term sukuk is about 12 years (mean $=11.660)$ and long term conventional bonds in range of 10 years (mean = 10.491). Justifying that, longer tenure of maturity leads to huge uncertainty and volatility of bond prices and yield spread and could mean huge possible return or loss [40] investigate the comovement pattern between sukuk and conventional bonds reported that the patterns do not seem to behave differently regards to frequency and time. Besides, negative interactive linkage between shariah stock and sukuk on daily 5-years data (July 10, 2008 - July 13, 2013) [42].
Many structures of sukuk which offers financing based on profit-sharing approach and ownership of sukukholders towards underlying asset make it investors eager to issue sukuk as well as conventional bonds. It can be seen through the mean and standard deviation results of long term sukuk (at 4.15 and 1.616 respectively) were competitively with long term conventional bonds (at 5.058 and 1.835 respectively). Even, Cochran and Cox [43] suggest that for raising fund through sukuk, the long term outcome of issuing sukuk needs to be considered.

Moreover, issuer characteristics also take into consideration in analyzing the mean different between long term conventional bonds and sukuk. In this category, the measurements are focus on firm's profitability, leverage, firm value, free cash flow, firm size and sustainability growth rate. To all this measurements, all mean value favors to long term conventional bonds compare to sukuk. It needs to highlight that, higher is better to the firm performance except for leverage. Higher leverage represent the liability obligation in term of interest payment to bondholder is high.

As reported in Table 2, yield spreads for long term sukuk and conventional bonds is significantly mean different demonstrate by F-value of Levene's test is 8.900 at 99 percent confident level.

Table 2: Comparison of Mean of Variables between Long Term Conventional Bonds and Long Term Sukuk

\begin{tabular}{|c|c|c|c|c|c|}
\hline \multirow{2}{*}{ Variables } & \multicolumn{2}{|l|}{ t-test } & \multirow[t]{2}{*}{$\begin{array}{l}\text { Mean } \\
\text { Difference }\end{array}$} & \multicolumn{2}{|c|}{ Levene Test } \\
\hline & $t$ & $p$ & & $\boldsymbol{F}$ & $p$ \\
\hline \multicolumn{6}{|l|}{ Dependent: } \\
\hline Yspreads & 2.384 & .018 & .491 & 8.900 & .003 \\
\hline \multicolumn{6}{|c|}{ Institutional Ownership : } \\
\hline Top-6 IO & 2.309 & .022 & 5.680 & 19.761 & .000 \\
\hline Other IO & -2.500 & .013 & -6.886 & 8.565 & .004 \\
\hline \multicolumn{6}{|c|}{ Board of Director Charateristics: } \\
\hline BOD Role Duality & -2.743 & .007 & -.154 & 31.097 & .000 \\
\hline BOD Composition & 1.083 & .280 & .022 & 5.306 & .022 \\
\hline BOD Size & -1.223 & .223 & -.387 & 1.641 & .201 \\
\hline BOD Muslim & -.229 & .819 & -.667 & .132 & .717 \\
\hline \multicolumn{6}{|c|}{ Issue Charateristics: } \\
\hline Volatility & 4.033 & .000 & .945 & 20.383 & .000 \\
\hline lnSize issue & 4.136 & .000 & .908 & 5.261 & .023 \\
\hline Tenure & -1.010 & .314 & -1.169 & .847 & .358 \\
\hline \multicolumn{6}{|c|}{ Issuer Charateristics: } \\
\hline Profitibility & .696 & .487 & .454 & .554 & .457 \\
\hline Leverage & 5.350 & .000 & 3.229 & 174.458 & .000 \\
\hline Firm Value & 1.852 & .065 & .068 & .527 & .469 \\
\hline Firm Size & 1.415 & .158 & .469 & 3.591 & .059 \\
\hline Sustainability & .954 & .342 & 1.056 & 9.163 & .003 \\
\hline \multicolumn{6}{|l|}{ Systematic Risks: } \\
\hline $\operatorname{lnGDP}$ & -1.706 & .089 & -.082 & 45.524 & .000 \\
\hline
\end{tabular}




\section{Noriza Mohd Saad / International Journal of Business and Management, 2 (2) 2018, Pages: 17-25}

Thus, the alternative hypothesis for the assumption of homogeneity of variance towards yield spreads is met and failed to reject. This result associated with the equal variances not assumed considering the Levene's test result by adjustment for the standard error of the estimation [43] and by adjustment for the degrees of freedom [44]. From the results it can be concluded that there is a significant mean different between them with a tvalue of 2.384 and p-value of 0.018 with 95 percent confidence level. The t-statistics is positive which indicates that the yield spreads of long term conventional bonds was higher means than the long term sukuk' yield spreads. It shows that the wider range of yield spreads representing by higher means of long term conventional bonds indicate the level of default risks is higher compare to trading in long term sukuk.

With respect to institutional ownerships by both proxies, presence of top-six institutional investors and others institutional investors in the long term investment through issuing sukuk and conventional bonds shows a F-value of Levene's test is 19.761 and 8.565 with a $p$-value of $0.000(p<0.01)$ and $0.004(\mathrm{p}<0.05)$ respectively. Therefore, again the alternate hypothesis for the assumption of homogeneity of variance towards presence of topsix and others institutional investors are met and were fail to reject. The results conclude that there is a significant mean different between them with a tvalue of 2.309 and -2.500 respectively and p-value of 0.022 and 0.013 at 95 percent confidence level respectively. Remarkably that, the mean different for the presence of top-six institutional ownerships higher in the issuer who was issued long term conventional bonds compare to the sukuk issuer denotes by positive value at 2.309 .

However, the others institutional investors denotes the $p$ value of Levene's test is at 0.004 with F-value of 8.565. Thus, the alternate hypothesis for the assumption of homogeneity of variance towards presence of other institutional investors is met and failed to reject. Negative sign of t-value at -2.500 reported by independent t-test result indicate that long term sukuk issuer have more share ownership from institutional investors compare to long term conventional bonds issuer. This institutional investors preferably to invest in those issuer who issued long term sukuk probably related to the t-test result of sukuk' yield spreads is slightly lower than conventional bonds as mentioned above. This investment decision can be classify them as risk adverse investors which refer to those investors who try to generate return at minimal risk with opportunities of chances given.

In term of BOD characteristics, BOD role duality show significant mean different otherwise BOD compositions show insignificant mean different results. Therefore, the alternate hypothesis for the assumption of homogeneity of variance towards the directors who hold two positions (as a chairman and also CEO) is met and failed to reject. However, the compositions of independent directors in the firms are not statistically significant mean different between conventional bonds and sukuk. Thus, the null hypothesis is met and failed to reject. The results conclude that there is a significant mean different in terms of role duality and compositions of independent directors in long term conventional bonds issuer and long term sukuk issuer. Results for t-value of BOD role duality shows a negative significant value $(\mathrm{t}=-2.743, \mathrm{p}=0.007)$ validate that higher mean favors to long term sukuk than long term conventional bonds issuer. Contrary, the BOD composition shows a positive insignificant value $(\mathrm{t}=1.083, \mathrm{p}=0.280)$ explain that higher mean favors to long term conventional bonds than long term sukuk issuer.

Another two proxies refer to BOD size and BOD Muslim show that their $\mathrm{p}$ values for Levene's test are insignificant with 0.201 and 0.717 respectively. Therefore, the null hypothesis is met and failed to reject for the assumption of homogeneity of variance towards the BOD size and BOD Muslim. Subsequently, the results conclude that there is no significant mean different for both proxies in long term conventional bonds and sukuk issuer.

In examining the significant mean different of issue characteristics, volatility $(\mathrm{p}=0.000)$ and size of issuances $(\mathrm{p}=0.023)$ shows a significance level at 1 percent and 5 percent of Levene's test at $F$ value of 20.383 and 5.261 respectively. Therefore, the results conclude that there is a significant mean different in terms of volatility and size of issuances in long term conventional bonds and long term sukuk. Besides, the results for $t$ value shows a positive significant value for both volatility $(t=4.033, p=0.000)$ and size of issuances $(t=4.136$, $\mathrm{p}=0.000$ ) validate that higher mean favors to long term conventional bonds than long term sukuk issuances. The fluctuation of uncertainty risk in bond coupon is higher compare to sukuk for long term period. Dissimilar result indicates by tenure of the issuances whereby the p-value is at 0.358 and Fvalue at 0.847 in the Levene's test shows that the hypothesis is met.

Thus, the results conclude that there is no significant mean different for tenure of sukuk or conventional bonds issuances in long term period. This finding was supported by the mean descriptive statistics results in Table 1 whereby both of instruments have tenure around 10 to 11 years in average indicate by mean different only at 0.314 .

Then, based on the issuer characteristics, leverage performance are obviously show the significant mean different between long term conventional bonds and sukuk issuer. It can be seen through Levene's test result of F-value at 174.458 with pvalue at $0.000(\mathrm{p}<0.001)$ represent 99 percent 
Noriza Mohd Saad / International Journal of Business and Management, 2 (2) 2018, Pages: 17-25

confident level. It revealed that $\mathrm{t}$-value of leverage shows a positive value and $\mathrm{p}$-value $(\mathrm{t}=5.350$, $\mathrm{p}=0.000$ ) report that long term conventional bonds issuer bearing more leverage represent by higher mean compare to long term sukuk issuer. Meaning that, the issuers need to face with high financial risk level when they make a decision to issue more debt in their capital structure. Other issuer characteristics that show a significant mean different are firm size and sustainability growth rate. The firm size shows a F-value and p-value is at 3.591 and 0.059. Then, sustainability growth rate shows a value of both, Fvalue and p-value is at 9.163 and 0.003 respectively. It explains that there is a mean different between these variables to the long term conventional bonds and sukuk issuer. Regardless to firm's profitability and firm value indicate insignificant value of Levene's test hence, the performance of the issuers is not significant mean different either they were issued long term conventional bonds or long term sukuk.

Accordingly, the results conclude that there is a significant mean different as regards to influential of systematic risks in long term conventional bonds and long term sukuk issuances. Results for t-value of this variable is also shows a negative significant value at -1.706 validate that higher mean favour to long term sukuk than long term conventional bonds issuances.

\section{CONCLUSIONS}

Yield spreads have significant mean different between conventional bonds and sukuk in long term issuances. The result also indicates a positive sign whereby conventional bonds yields have larger spread compared to sukuk. Remarkably, the findings suggested that financing with long-term sukuk may reduce a default risk since larger deviation of yield spreading in their yield to maturity lead to bearing higher interest or profit sharing in their contract obligation. Next, both proxies of institutional ownerships either top-6 or others show that there are significant mean different of institutional ownerships in long term issuance.

Even through their top-6 institutional ownerships presence is larger in conventional bonds issuer firm however other institutional ownerships is larger in sukuk issuer firms. Higher ownerships belong to the company make them active in monitoring role in order to ensure the shareholder wealth maximization can be achieved as ownership theory applied. With respect to BOD characteristics, only BOD role duality has significant mean different that issuer firm who was issued long term sukuk has a separate position between chairman and CEO in their BOD structure.

Nevertheless, another three of BOD characteristics show an insignificant mean different between conventional bonds and sukuk. The overall issue and issuer performance shows that they behave differently depending on the types of debt instrument in their structure of capital financing either by long-term sukuk or conventional bonds.

\section{REFERENCES}

[1] Clifford, C. (2008); Introduction to Islamic Bond. Available at http://www.cliffordchance.com.

[2] Manaf, I.A. (2007). 'Islamic bonds (Islamic Bond): Its introduction and application'. Available at http://www.sebi.ac.id/

[3] Shahrim, Z. (2006), "Islamic Bonds (Islamic bonds): A Malaysian perspective".

[4] Alam, N., Hassan, M.K., and Haque, M.A. (2013); Are Islamics Bonds different from conventional bonds? International evidence from Capital Market Tests, Borsa Istanbul Review 13, 22-29.

[5] Alvi, I.A. (2006), Increasing the Secondary Market for Islamic Bonds: Overview and Considerations. Available at http://www.iifm.net

[6] Alvi, I.A. (2007), Need for a Global Unified Islamic Bonds Market: Key Challenges \& Role of Islamic Financial Institution. Available at http://www.iifm.net.

[7] Ashbaugh-Skaife, H., Collins, D.W. and LaFond, R. (2006); The Effects of Corporate Governance on Firms' Credit Ratings, Journal of Accounting and Economics 42, Issues 1-2, 203-243.

[8] Bhojraj, S. and Sengupta, P. (2003); Effects of Corporate Governance on Bond Ratings and Yields: The Role of Institutional Investors and Outside Directors, Journal of Business 76, 455476.

[9] Anderson, R.C., Mansi, S.A, \& Reeb, D.M. (2003); Founding family ownership and the agency cost of debt, Journal of Financial Economics 68, 263-285.

[10] Weber, J. (2006); Discussion of the Effects of Corporate Governance on Firms' Credit Ratings, Journal of Accounting and Economics 42, 245-254.

[11]Ertugrul, M. and Hegde, S. (2008); Board Compensation Practices and Agency Costs of Debt, Journal of Corporate Finance 14, 512531.

[12] Mungniyati (2009); The Effect of Corporate Governance and Earnings Information on Bond Ratings and Yields, Jurnal Bisnis Dan Akuntansi, Vol.11, No.2, Agustus 2009, 129141.

[13]Liu, Y., and Jiraporn, P. (2010); The Effect of CEO Power on Bond Ratings and Yields, Journal of Empirical Finance, 17(4), 744-762.

[14][14] Boubakri, N. and Ghouma, H. (2010); Control/Ownership Structure, Creditor Rights 
Protection, and the Cost of Debt Financing: International Evidence, Journal of Banking \& Finance, Vol. 34, Issue 10, October 2010, 2481-2499.

[15] Bradley, M. and Chen, D. (2011); Corporate Governance and the Cost of Debt: Evidence from Director Limited Liability and Indemnification Provisions, Journal of Corporate Finance 17, 83-107.

[16] Becker, B. and Ivashina, V. (2012); Reaching for Yield in the Bond Market, Harvard Business School Finance Working Paper No. 12-103/ (December 2012)/ March 2013. Available at: http://dx.doi.org/10.2139/ssrn.2065841

[17] Jiraporn, P., Chintrakarn, P., Kim, J-C and Liu, Y. (2012); Exploring the Agency Cost of Debt: Evidence from the ISS Governance Standards. Available at: http://dx.doi.org/10.2139/ssrn.2062104

[18] Alali, F. A, Anandarajan, A. and Jiang, W. (2012); The Effect of Corporate Governance on Firm's Credit Ratings: Further Evidence Using Governance Score in the United States, Journal of Accounting \& Finance, Vol. 52, Issue 2, 291312.

[19] Berle, A. and Means, G. (1932); The Modern Corporation and Private Property, California Law Review 21(1), 78-79.

[20] Wu, C. \& Liu, I-Hsuan (undated). Market Liquidity, Corporate Governance and Firm Value - Taiwan Evidences. Available at: http://www.wbiconpro.com/323-Chiming.pdf.

[21] Elyasiani, E., Jia, J. (Jane) and Mao, C.X. (2010); Institutional Ownership Stability and the Cost of Debt, Journal of Financial Markets 13(4), 475-500.

[22] Jobst A., Kunzel, P. Mills, P. \& Sy, A.(2008), Islamic Bond Issuance-What Sovereign Debt Managers Need to Know. Available at: http://www.imf.org/external/pubs/ft/pdp/2008/ pdp03.pdf

[23] Suchard, J-A., Pham, P. K. and Zein, J. (2012); Corporate Governance and the Cost of Capital: Evidence from Australian Firms, Journal of Applied Corporate Finance 24(3), 84-93.

[24] Endri (2011); Corporate Governance Terhadap Peringkat Sukuk Korporasi di Indonesia, Jurnal Keuangan dan Perbankan, 15(2), 178-190.

[25] Afiani, D. (2013); Pengaruh Likuiditas, Produktivitas, Profitabilities dan Leverage Terhadap Peringkat Sukuk (Studi Empiris Pada Bank Umum Syariah dan Unit Usaha Syariah Period 2008-2010), Accounting Analysis Journal (AAJ) 1 (3), 110 -115.

[26] Minority Shareholder Watchdog Group (MSWG) and Securities Commission (SC) (2014). Malaysia-Asean Corporate Governance Report 2014. Available at: https://www.mswg.org.my/sites/default/files/M alaysia-
ASEAN_Corporate_Governance_Report_2014 upload_0.pdf

[27] The Malaysian Code for Institutional Investors 2014 (MCII, 2014). Public Response Paper No. 1/2014. Available at: https://www.sc.com.my/wpcontent/uploads/eng/html/consultation/140626 PublicResponse_1.pdf

[28] Box, T. and Asaria, M. (2005). Islamic finance market turns to securitization. International Finance Law Review 7, 22; M. J. T. McMillen, "Contractual Enforceability Issues: Sukuk and Capital Market Development" [2006-2007] Chicago Journal of International Law, 427-429.

[29] Saeed, A. \& Salah, O. (2014). Development of Sukuk: Pragmatic and Idealist Approaches to Sukuk Structures. Journal of International Banking Law and Regulation 1, 41-52.

[30] Taqi Usmani, M. (2007). Sukuk and their Contemporary Applications. (Translated from the original Arabic by Sheikh Yusuf Talal DeLorenzo), AAOIFI Shari'a Council Meeting, Saudi Arabia. Available at http://www.kantakji.com/media/7747/f148.pdf

[31] Mohamed, H. H., Masih, M., \& Bacha, O. I. (2015). Why Do Issuers issue Sukuk or Conventional Bond? Evidence from Malaysian Listed Firms Using Partial Adjustment Models. Pacific-Basin Finance Journal. doi:10.1016/j.pacfin.2015.02.004.

[32] Mosaid, F. \& Boutti, R. (2014). Sukuk and Bond Performance in Malaysia. International Journal of Economics and Finance, 6(2), 226234.

[33]Fathurahman, H. and Fitriati, R. (2013), Comparative Analysis of Return on Sukuk and Conventional Bonds, American Journal of Economics, 3(3), 159-163.

[34] Ramasamy, R., Munisamy, S. \& Mohd Helmi, M.H. (2011). Relative Risk of Islamic Sukuk Over Government and Conventional Bonds. Global Journal of Management and Business Research 11(6). Version 1.0 May 2011. Publisher: Global Journals Inc. (USA).

[35] Safari, M., Ariff, M. and Mohamed, S. (2013), Do Debt Markets Price Sukūk and Conventional Bonds Differently?, Journal of King Abdul Aziz University (JKAU): Islamic Economies, 26(2), 113-149

[36] Cakir , S.and Raei , F (2007) "Sukuk vs. Eurobonds: Is There a Difference in Value-atRisk? Available at: http://www.imf.org/external/pubs/ft/wp/2007/ wp07237.pdf

[37]Ellis, T.R. (2012), The Piety Premium of Islamic Bonds, Middle East Quarterly Spring 2012, 61-72.

[38] Jabeen, Z. and Javed, M.T. (2007); SUKUKStructures: An Analysis of Risk-reward Sharing and Wealth Circulation, The Pakistan 
Noriza Mohd Saad / International Journal of Business and Management, 2 (2) 2018, Pages: 17-25

Development Review 46: 4 Part II (winter 2007), 405-419.

[39] Godlewski, C.J., Turk-Ariss, R. \& Weill, L. (2013), Sukuk vs. conventional bonds: A stock market perspective, Journal of Comparative Economics 41, 745-761.

[40] Aloui, C., Hammoudeh, S. \& Hamida, H.B. (2015a), Global factors driving structural changes in the co-movement between sharia stocks and sukuk in the Gulf Cooperation Council countries, North American Journal of Economics and Finance 31, 311-329.

[41] Gitman, L. J. and Zutter, C.J. (2012), Principles of Managerial Finance, Thirteenth Edition. Pearson.
[42] Aloui, C., Hammoudeh, S. \& Hamida, H.B. (2015b), Co-movement between sharia stocks and sukuk in the GCC markets: A timefrequency analysis, Journal of International Financial Markets, Institutions \& Money 34, 69-79.

[43] Cochran, W.G., \& Cox, G.M. (1957). Experimental Designs. New York:John Wiley \& Sons.

[44] Satterthwaite, F.W. (1946). An Approximate Distribution of Estimates of Variance Components. Biometrics Bulletin 2, 110-114. 